Józef Matuszewski

\title{
Prawo niemieckie w Statutach Kazimierza Wielkiego*
}

\section{Deutsches Recht in den Statuten von Kasimir dem Großen}

1. Prawo niemieckie na polskiej wsi. 2. Ius Theutonicum = własność podzielona 3. Ius Theutonicum prawem materialnym polskiej wsi? 4. Dualizm sądownictwa wiejskiego. 5. Statutowe artykuły o prawie niemieckim. 6. Desuetudo. 7. Roszczenie wzajemne. 8. Podpalenie. 9. Gwałt niewieści. 10. Ucieczka kmiecia. 11. Chlopskie prawo wychodu. 12. Rewindykacja poddanych. 13. Wnioski. 14. Teksty

1. Deutsches Recht im polnischen Dorf. 2. Ius Theutonicum $=$ geteiltes Eigentum. 3. Ius Theutonicum als Sachenrecht des polnischen Dorfes? 4. Dualismus des dörflichen Gerichtswesens. 5. Statutsartikel über deutsches Recht. 6. Desuetudo. 7. Gegenforderungen. 8. Brandstiftung. 9. Weibesgewalt. 10. Bauernflucht. 11. Bäuerliches Ausgangsrecht. 12. Revindikation der Untertanen. 13. Schlussfolgerungen

* SKRÓTY: AKP - Archiwum Komisji Prawniczej [Kraków]; HPiPP I - Historia państwa i prawa Polski, t. 1, red. J. B a rdach, wyd. 2, Warszawa 1964; Hube I - R. Hube, Prawo polskie w wieku XIII, Warszawa 1874; Hube II - R. Hube Prawo polskie w 14-tym wieku. Ustawodawstwo Kazimierza Wielkiego, Warszawa 1881; Hube III - R. $\mathrm{H}$ ube, Prawo polskie w 14-tym wieku. Sqdy, ich praktyka i stosunki prawne spoleczeństwa $w$ Polsce $k u$ schylkowi 14-tego wieku, Warszawa 1886; KDW - Kodeks dyplomatyczny Wielkopolski; RH - „Roczniki Historyczne”; RKJ LTN - „Rozprawy Komisji Językowej Lódzkiego Towarzystwa Naukowego"; SUb - Schlesisches Urkundenbuch, oprac. i wyd. H. Appelt, W. Irgang, J. J. Menzel. 
1.1. Król Kazimierz głosił hasło: unum ius... in toto regno haberi debet, ne sit sicut monstrum (reg. B. II art. 116) ${ }^{1}$. Ustawodawcy chodziło $w$ istocie o likwidację różnic dzielnicowych między Mało- i Wielkopolską; mieszkańców obu tych prowincji traktowal bowiem jako eadem gens. Zamierzenia swego jednak nie zdołał urzeczywistnić, jedności sądownictwa nie przeprowadził ${ }^{2}$.

1.2. Do realizacji idei za jego czasów daleko. Wiemy, że w Polsce za obowiązujące obok prawa polskiego uważano także obce normy, kościelne wraz z rzymskimi, niemieckie ${ }^{3}$, żydowskie, ormiańskie i mahometańskie ${ }^{4}$. Przejęto je zresztą już dawno. Sam Kazimierz - wiemy - wystawił niemało przywilejów, nadających ius Teutonicum ${ }^{5}$. Co więcej, mówi się o tymże

${ }^{1}$ Pełny artykuł brami: Cum sub uno principe eadem gens diverso iure non debeat frui, ne sit tamquam monstrum, diversa habens capita, expedit publice rei, ut uno et equali iudicio tam Cracovienses quam Poloni iudicentur, Hube II, s. LI, art. 35; cytuje J. B a rd a ch, HPiPP I, s. 185. O potrzebie jedności prawa mowa już $\mathrm{w}$ prologu do Statutów: ...plereque cause in iudiciis non uniformiter, sed secundum capitum seu animarum diversitatem, quamvis super uno et eodem facto vario et diverso modo deciduntur et diffiniuntur, oraz $\mathrm{w}$ art. 38, s. LI: item ex quo unus princeps, unum ius, una moneta in toto regno debet haberi; ostatni artykuł cytuje $\mathrm{M}$. H a n d elsm a n, Kara w najdawniejszym prawie polskim, Warszawa 1907, s. 23.

${ }^{2}$ Por. Hube II, s. 220, oraz J. B ard a ch, HPiPP I, s. 368-371.

3 Że można to niemieckie prawo rozumieć na różny sposób, usiłowaliśmy wykazać na innym miejscu.

${ }^{4}$ Hube II, s. $20 \mathrm{n}$. Nawet poszczególne klasy społeczne używały każda innego systemu karnego, stwierdza M. H andelsm a n, Kara..., s. 99.

${ }^{5}$ W samym Kodeksie Wielkopolskim znaleźliśmy 22 tego rodzaju dyplomy; dwa $\mathrm{z}$ nich pozwalaja iure Theutonico seu Polonico locare ( $\mathrm{nr} 1300$ r. 1350 - dla Mazowsza, nr 1464, r. 1362, dla Wielkopolski), inny - przewiduje lokacje iure Teutonico vel alio quocumque, prout eis videbitur melius expedire, nr 1606, r. 1368. Zaznaczmy wszakże, że duża liczba dokumentów wielkopolskich Kazimierza nie zawiera w ogóle wzmianki o niemieckim prawie, choć w nich mowa o lokacji w lesie, np. nr 1479, KDW 3, r. 1362. 
prawie w jego Statutach, choć artykułów wzmiankujących o nim jest niewiele: naliczyliśmy ich zaledwie pięć, na ogólną liczbę blisko $170^{6}$.

1.3. Prawo niemieckie odgrywało dużą rolę na wsi polskiej; oczywiście obok prawa polskiego. Poddani siedzieli na prawie ziemskim - in iure terrestri, a zatem polskim; bądź na prawie niemieckim - quando vero kmetho in iure Teutonico residebat ${ }^{7}$. Wszakże niektóre artykuły statutów do tego rozróżnienia nie przywiązują już wagi, postanowienia ich dotyczą wszystkich poddanych, bez względu na to, jakim się rządzą prawem ${ }^{8}$.

1.4. Prawo niemieckie zawdzięczało swe rozpowszechnienie korzyściom, jakie przysparzało wszystkim uczestnikom akcji kolonizacyjnej: monarsze, właścicielom ziemskim i chłopom - beneque animadvertendo, quod ius Theutonicum nobis et nostris regnicolis multas affert utilitates, commoda multiplicat subditorum ${ }^{9}$. $\mathrm{Na}$ wsi ius Teutonicum stanowiło przede wszystkim normy skierowane na pozyskanie chłopa-kolonisty ${ }^{10}$. To w pierwszej linii było prawo chlopskie ${ }^{11}$ (por. niżej, ust. 2.2).

1.5. Wśród polskich aglomeracji „niemieckie" osady stanowiły zrazu wyjątek. Liczba ich wszakże rosła ustawicznie. W końcu wszystkie miasta rządziły się $u$ nas prawem niemieckim. Nie

${ }^{6}$ Wiemy, że podział Statutów na artykuły nie jest w różnych rękopisach identyczny.

${ }^{7}$ Hube II, s. 184.

${ }^{8}$ Statuty nie wyróżniają też osobnych kategorii ludności wiejskiej, choć w czasach Kazimierza nie była ona jednolita.

${ }^{9}$ Dokumenty do dziejów Kujaw i Ziemi dobrzyńskiej XIV-XIX w., wyd. Z. Guldon, R. Kabaciński, M. Kallas, J. Wojciak, Warszawa-Poznań 1974, s. 21, nr 1, r. 1317.

${ }^{10}$ Tak jak w mieście prawo miejskie mialo zwerbować mieszczan. Zauważ: w obydwu wypadkach uprzywilejowało plebs!

${ }^{11}$ Tymczasem chłopów pominięto $w$ przywileju Kazimierza dla sędziego kujawskiego 1362 r., KDW 6, nr 198. 
możemy niestety stwierdzić, jaki procent stanowiły ostatecznie obdarzone tym prawem osady wiejskie. Odnosimy wrażenie, że było ich dużo, tym bardziej że podkreślają to Statuty Kazimierzowskie: plures sunt nostri milites ius Theutunicum habentes in multis ipsorum villis. Zaakcentujmy: i plures (milites), i multae (villae).

1.6. Statuty Kazimierza Wielkiego stanowily pierwszy, obszerny akt ustawodawczy, poruszający kwestię prawa niemieckiego. Zajmują się nim jeszcze późniejsze Constituciones et iura terrae

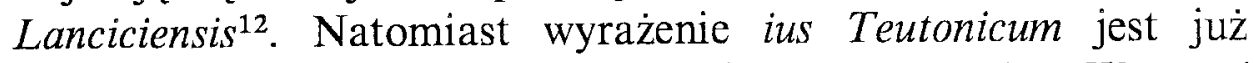
obce Statuta terrestria in conventionibus Cracoviensi et Wartensi laudata, choć $\mathrm{w}$ nich również mowa o soltysach, o kmieciach oraz o ich zbiegostwie ${ }^{13}$, zagadnieniach, którymi prawo niemieckie zajmowało się tak żywo.

1.7. Poruszony tu problem, który historykowi prawa wydaje się wciąż istotny, nie interesuje zupełnie Długosza. A przecież dla zaznaczenia wskazanej kwalifikacji prawnej stanowił Liber beneficiorum okazję wręcz wyjątkową; aż się prosilo, żeby obok tylu szczegółów, notowanych $\mathrm{z}$ taką starannością przez naszego dziejopisa, zaznaczyć choćby słowem, jakim się rządzi wieś prawem - polskim czy niemieckim. A tymczasem nic z tego. Długosz uporczywie milczy, problemu w ogóle nie dostrzega, dla niego on nie istniał, choć własność podzielona, istotny wkład prawa niemieckiego do dziejów naszego prawa, stał się dorobkiem trwałym, czego był prawdopodobnie nieświadomym świadkiem. Dla niego układ ziemski, stosunek osobisty i rzeczowy między panem a chłopem, stanowił już instytucję polską!

2.1. Przypomnieliśmy niedawno, co dla wystawców i odbiorców przywilejów lokacyjnych znaczyło w stuleciach 13.-14. ius

\footnotetext{
12 AKP, t. 4 [1921], Jag. II, art. 1, 39, 42, 44, 46, 50.

13 AKP, t. 4 [1921], Warsz. art. 23, 24.
} 
Teutonicum ${ }^{14}$. W istocie kryło się w tym wyrażeniu wprowadzenie na wieś polską dwuwłasności, owej charakterystycznej dla europejskiego średniowiecza własności podzielonej ${ }^{15}$. Nadanie chłopu praw rzeczowych do gruntu, jego uwlaszczenie, było istotną, najistotniejszą treścią niemieckiego prawa. Wreszcie zostawał chłop właścicielem ziemi. Niewątpliwy to dla niego sukces majątkowy, a równocześnie i społeczny. Takiej pozycji nie zapewniał mu immunitet. Wszakże to dopiero pierwszy stopień uwłaszczenia. Albowiem nadana mu własność nie była całkowita; równocześnie bowiem pan pozostawał dalej verus dominus et proprietarius ${ }^{16}$. Na następny etap, na pelną własność, poczeka kmieć polski jeszcze parę stuleci, do reform agrarnych 19. stulecia.

2.2. Zapytujemy teraz, czy równocześnie $\mathrm{z}$ tym procesem uwłaszczenia (nazwijmy je uwlaszczeniem pierwszego stopnia) dokonywała się recepcja niemieckich reguł prawnych, niemieckiego prawa osobistego, formalnego i materialnego. A więc nie tylko „gospodarstwo", ale i ,prawo"17.

${ }^{14} \mathrm{~J}$. M a t uszewski, Ius Teutonicum. Średniowieczna reforma rolna w Polsce, [w:] Zagadnienia prawa konstytucyjnego. Ksiega pamiatkowa ku czci prof. Tadeusza Szymczaka, Lódź 1994; t e ṅ̇e, Prawo sądowe na wsi polskiej lokowanej na prawie niemieckim, [w:] Studia z dziejów państwa i prawa polskiego, t. II, Łódź 1995; t e nże, Rodzaje wlasności gruntu we wsi lokowanej na prawie niemieckim, [w:] Parlament, prawo, ludzie. Studia ofiarowane profesorowi Juliuszowi Bardachowi, Warszawa 1996, s. 158-164.

15 Problemu tego nie widzial Romuald Hube. Jego zdaniem, kmiecie i inni ludzie, osiedli w dobrach szlachty i duchowienstwa czy to na prawie niemieckim, czy polskim, mieli tylko prawo użytkowania posiadanych przez siebie siedzib. Utrzymywało się ono tak długo, jak długo na nich siedzieli. Miało to - jego zdaniem - wynikać z rozporządzeń Statutu nie zapewniających im żadnego wynagrodzenia ze strony panów w razie, gdy takowe opuszczają, Hube II, s. 123-124, 193.

161360 r., KDW 3, nr 1442.

${ }^{17}$ K. T y mieniecki, Prawo czy gospodarstwo, [w:] RDSG 8 (1939-1946) Poznań 1996; t e nż e, Lenna chlopskie czy prawo niemieckie, RH 1951/52, nr 20, s. 59-114. 
2.3. Tekst łaciński dokumentów - zdawałoby się - narzuca wręcz jedno ich rozumienie: nadawano niedwuznacznie ius (Teutonicum), (niemieckie) prawo! Tak też pojmowali owe nadania współcześni; przejęli tę interpretację za swoją również dawniejsi historycy. Czyżby rzeczywiście - zapytujemy ponownie - wraz $\mathrm{z}$ własnością podzieloną wprowadzano dla chłopów polskich równocześnie niemieckie prawo osobiste?

2.4. Żeby odpowiedzieć na to pytanie, zastanówmy się, czy między omawianymi zjawiskami (nabycie przez chłopa własności podrzędnej - $\mathrm{z}$ jednej strony, oraz recepcją niemieckiego prawa $-\mathrm{z}$ drugiej) istnieje związek konieczny. Bez wahania damy tu odpowiedź negatywną. Łatwo bowiem wyobrazić sobie sytuację, w której pan dzieli się z poddanym własnością gruntu, nadając $\mathrm{mu}$ własność użytkową na jednym lanie $^{18}$, ale równocześnie zostawia go przy dawnych consuetudines, przy jego prawie osobistym.

2.5. A zresztą, czy w 14. w. pan miał taką moc nad chłopem, by zmieniać samowolnie istniejące consuetudines rusticorum i w ich miejsce wprowadzać nowe? Wydaje się to mało prawdopodobne! Obawiamy się, że jego usiłowania we wskazanym kierunku napotkałyby na spontaniczny i bierny opór konserwatywnej z natury społeczności wiejskiej.

2.6. Nie sądzimy też, by panu w ogóle zależało na porzucaniu przez poddanych ich odwiecznych consuetudines i zastępowaniu nowymi. Czy miał w tym jakikolwiek interes? Przy lokacji chodziło mu jedynie o zapewnienie sobie stałych czynszów $i$ innych periodycznych świadczeń. Skoro już to osiągnął, racjonalna wydawać się musiała poza tym postawa bierna: nie

18 To reguła; znacznie rzadziej otrzymywał chłop więcej łanów, ale wtedy już z zastrzeżeniem: najwyżej dwa - quodque nullus villanus seu incola ibidem plus quam duos mansos debeat obtinere; Dokumenty do dziejów Kujaw..., s. 38 , nr 4, r. 1343. 
zniechęcać do siebie osadnika na żaden sposób, a więc także nie narzucać mu nowych praw, lecz pozostawić go przy dawnych zwyczajach, do których wieśniak tak byl przywiązany. A właśnie dzięki takiej pasywnej postawie pana doszło w Polsce rzeczywiście do pojawienia się niemieckiego prawa, materialnego i formalnego!

3.1. Wszakże $z$ pewnym ograniczeniem $i$ to istotnym. Wprowadzenie obcego prawa, owego ius Teutonicum, dokonywało się w wypadku kolonizacji ludnością niemiecką ${ }^{19}$. Nie ulega dla nas wątpliwości, że wówczas, gdy osadnikami byli chłopi-Niemcy, zgodnie z zasadą osobowości praw, zachowywali oni dalej, na nowej siedzibie, w Polsce, swoje prawo osobiste, a zatem niemieckie.

3.2. Osadnictwo Niemcami poczytać musimy jednak za zjawisko marginesowe. Trzon lokacji stanowila zawsze ludność miejscowa, a zatem polska. Czyżby ona - zapytujemy $-\mathrm{z}$ chwilą lokacji na prawie niemieckim, a więc $\mathrm{z}$ chwilą nadania jej własności użytkowej, recypowała także niemieckie prawo sądowe? Tu leży problem.

3.3. Niemały kłopot $\mathrm{z}$ akceptacją takiego poglądu! Zważmy, że było to prawo zwyczajowe. Niemcy-koloniści przynosili swoje zwyczaje ze sobą, oni je znali. Ale, jak miałoby dojść do recepcji tychże norm przez osadników polskich? Niemieckiego prawa chłop polski nie znał notorycznie, nie mógł go też sobie przyswoić od razu, z chwilą wystawienia przywileju lokacyjnego. Kto miał bowiem polskiego analfabetę obcego prawa nauczyć? Siłą rzeczy materialne prawo niemieckie nadal pozostawało dla

19 Poza Niemcami słyszymy też o kolonistach innych narodowości, np. Walonach, (por. tu J. J. M e nze l, Die schlesischen Lokationsurkunden des 13. Jahrhunderts, Würzburg 1977, s. 218-219), ale to kwestia marginalna. 
polskiego osadnika obce. Tak być musiało! ${ }^{20}$ Inna natomiast rzecz z organizacją sądową.

4.1. $\mathrm{Tu}$ tkwiła istota innowacji, związanej $\mathrm{z}$ nadaniem prawa niemieckiego. Obdarzony immunitetem pan - wiemy - stawał się u siebie najwyższą instancją sądową. Nie wyobrażamy go sobie wszakże jako siedzącego za biurkiem urzędnika, oddanego wymiarowi sprawiedliwości w swoim państwie. $\mathrm{Na}$ to on za wielki, by trudzić się na co dzień sporami poddanych. Funkcję tę zleci przeto bez wahania komu innemu, powoła do życia osobny sąd, złożony z sołtysa jako przewodniczącego (nie bez racji zwie się on nieraz $\mathrm{w}$ dokumentach iudex) i chłopskiej lawy. Sami w niej plebeje! To było istotne nowum organizacyjne, związane $\mathrm{z}$ prawem niemieckim: samorządne sądownictwo chłopskie ${ }^{21}$. Oczywiście pozostawało ono zawsze pod zwierzchnością pańską.

4.2. W rezultacie lokacji na prawie niemieckim występowały na wsi naszej dwa rodzaje sądów: polskie, pełnione przez sądy ziemskie (jeszcze nie stanowe - szlacheckie) oraz niemieckie, odbywane przez chłopskie samorządne sądy prawa niemieckiego - iudicium iuris Theutonici. W pierwszych trzymano się oczywiście prawa polskiego, dla drugich podstawą miało być prawo niemieckie.

4.3. Zrozumiałe, że przy tym nowym układzie - równoczesne dwa rodzaje sądów (rodzime, polskie i obce, niemieckie) oraz dwa rodzaje praw (znowu polskie i niemieckie) - mogło do-

${ }^{20} \mathrm{Zu}$ deutschem Recht an- und umgesetzte Polen haben vermutlich ganz entsprechend [...] ihr altes polnisches Gewohnheitsrecht vorerst ganz oder teilweise beibehalten, J. J. M e nze 1, Die schlesischen..., s. 287.

${ }^{21}$ Tak się przynajmniej wydaje w sytuacji, gdy z braku źródeł nie wiemy absolutnie nic o tym, jak przedstawiało się na wsi polskiej sądownictwo poimmunitetowe. Czy już wówczas - a zatem jeszcze przed pojawieniem się prawa niemieckiego - pan nie przelewał części swych uprawnień sądowych na chłopów? Niełatwo nam bowiem wierzyć w jego gorliwość sędziowską. Tymi wątpliwościami dzieliliśmy się już dawniej. 
chodzić do nieładu ${ }^{22}$, rodził się konflikt praw $^{23}$. W praktyce nasuwała się trudność $\mathrm{z}$ wyborem prawa: stosować ius Teutonicum czy Polonicum? Mogło to prowadzić do nadużyć24. Rzeczywiście, Statuty Kazimierzowskie konstatują, że właśnie $\mathrm{z}$ wskazanego co tylko powodu przestępstwa uchodzą często bezkarnie, et sic sepius talium maleficorum crimina remanent impunita. Przestępcy, którzy winni odpowiadać przed właściwym dla nich sądem polskim, chcąc ujść grożącej im represji (ut manus effugiant iusticie, ipsos punire volencium $\left[{ }^{25}\right],[\ldots]$ ut facilius eludant commissi criminis accionem, [...] ut accionem propositam contra eos eludant vel claudant), uciekają do miast $\mathrm{i}$ wsi lokowanych na prawie niemieckim, consueverunt tales omnes [...] in civitatibus vel villis Teutunicalibus permanere. Tutaj już podszywają się pod niemieckie normy, iure Theutunico volunt se tueri, bronią się per iuris Theutunici defensionem. Przy tym - co Statuty akcentują - dzieje się to bardzo często - $u t$ plurimum $^{26}$. Z tym niepożądanym zjawiskiem nie mógł się panujący pogodzić, nadużyciom pragnął zapobiec. Jakie tu Kazimierzowskie Statuty przewidują na nie sposoby?

5.1. Nie oczekujmy wszakże od nich zbyt wiele, jakiegoś globalnego rozwiązania konfliktu praw, polskiego i niemieckiego. W Statutach - wiadomo - góruje kazuistyka, znajdujemy w nich rozwiązania konkretnych wypadków, de omicidio, de lusoribus taxillorum, de usura, de dote et donacionibus, de penis, de scropha, de moneta, de expedicione, de iure militum. Artykułów zajmujących

${ }^{22}$ M. H a ndelsman, Kara..., s. 178.

${ }^{23} \mathrm{M}$. H andelsman, Prawo karne $w$ statutach Kazimierza Wielkiego, Warszawa 1909, s. 102-103.

${ }^{24}$ Tak już Hube II, s. 23.

${ }^{25}$ Charakterystyczny dla pisarza-Polaka błąd interferencyjny, por. J. M a t us zews ki, Folia, RKJ LTN 1995, t. XL, s. 187-196.

${ }^{26}$ Por. też cytat $\mathrm{z}$ ust. 1.3 . 
się prawem niemieckim jest zresztą - wiemy już - niewiele ${ }^{27}$. Jaka ich treść?

5.2. Dwa $z$ nich dotyczą kwestii formalnych:

(1) desuetudo prawa niemieckiego oraz

(2) roszczenia wzajemnego strony pozwanej.

Trzy dalsze przewidują sankcje karne za następujące ,zbrodnie”:

(3) podpalenie,

(4) gwalt niewieści ${ }^{28}$ oraz

(5) zbiegostwo $\mathrm{kmieci}^{29}$.

I to wszystko, co w Statutach posiada związek z niemieckim prawem. Nie jesteśmy w stanie stwierdzić, co skłoniło autorów Statutów do takiego właśnie wyboru ${ }^{30}$. Zanalizujmy owe artykuły po kolei. Rozpoczynamy od przepisów proceduralnych ${ }^{31}$.

6.1. Kwestia pierwsza, desuetudo iuris Teutonici - B IV, art. 35; ustawodawca stwierdza możliwość wyjścia prawa niemieckiego $\mathrm{z}$ użycia, et tamen iure Teutonico obmisso...

6.2. Informacja zaskakuje historyka. Czytelnik naszych dyplomatariuszy odnosi - zdawałoby się nie do odparcia - wrażenie masowości nadań prawa niemieckiego. Wydaje mu siẹ zatem,

27 Por. wyżej, ust. 1.2.

${ }^{28} \mathrm{Te}$ dwa występki, zaliczające się do najcięższych, weszły w statucie warckim z $1423 \mathrm{r}$. w skład czterech artykułów grodzkich, K. K or a n y i, $W$ sprawie genezy czterech artykulów starościnsskich, [w:] Sprawozdania Towarzystwa Naukowego we Lwowie 1931, R. 11, s. 20, 22.

${ }^{29}$ To same Statuty zmuszają do postawienia przepisu o zbiegostwie $\mathrm{w}$ towarzystwie wspomnianych zbrodni.

${ }^{30}$ Inne ciężkie przestępstwa w rodzaju grabieży itp. nie zostały w Statutach uwzględnione w związku $\mathrm{z}$ prawem niemieckim.

31 Oczywiście dla pełności obrazu uwzględnimy niejednokrotnie także te artykuły, które choć nie wspominają w ogóle o prawie niemieckim, to wiążą się $\mathrm{z}$ nim treścią. 
że w ich następstwie cała Polska, miasta i wsie, korzystając z nadarzającej się możności, concessa sibi potestate, rządzą się wspomnianym niemieckim prawem. Tymczasem sprawa nie przedstawia się tak prosto; zdarza się, że nadanego prawa niemieckiego nie zawsze ludność przestrzega, że wraca nieraz do zwyczajów polskich, tamen secundum ius Polonicum se regunt in quibusdam!

6.3. Powolując się na postanowienia świętych ojców Kościoła, patrum sanctorum decreta, stwierdzają Statuty, że zgodnie $\mathrm{z}$ tymi dekretami, uprawnienie traci ten, kto $\mathrm{z}$ niego nie korzysta, lex decernat illos amittere privilegii auctoritatem, qui non utuntur in eo. Od tej zasady nie jest wyłączone i ius Teutonicum. Także ono przestaje nieraz być stosowane w praktyce (por. ustęp poprzedni). W takiej sytuacji, gdy dokonała się desuetudo niemieckiego prawa, nie wolno już więcej na nie się powoływać, statuimus, quod amplius per ius Teutonicum contra agentes non poterint se defensare, lecz należy postępować w sposób następujący: wyrokować zgodnie ze zwyczajem praktykowanym faktycznie w danej miejscowości, w czasie, w którym dopuszczono się zbrodni - volumus, quod ubi crimen est commissum, illo iure, quo illa villa tunc usa fuit, debebit iudicari sive terminari. A więc we wsi, w której nie respektuje się już nadanego jej niegdyś niemieckiego prawa, należy karać przestępców nie zgodnie z tym prawem, lecz stosować normy polskie!

7. Kwestia druga, reconventio, przeciwroszczenie pozwanego - B IV, art. 31.

7.1. Przytaczając powszechnie obowiązującą zasadę właściwości sądu pozwanego, cum actor forum rei undique sequi debeat, rozpatrują Statuty następujący problem: sprawa toczy się już przed sądem prawa niemieckiego - si quis in iudicio iuris Tewthunici contra reum suam accionem dirigit aut proponit (widocznie reus temu niemieckiemu prawu podlega); czy wolno 
pozwanemu w toczącym się już przed sądem niemieckim procesie wystąpić z przeciwroszczeniem do powoda, który najwidoczniej podlega prawu polskiemu ${ }^{32}$ ut [...] reus accionem vel actorem ibidem super alia questione [...] reconvenire poterit. Przy występowaniu roszczenia wzajemnego wydawałoby się takie postępowanie jak najbardziej uzasadnione. Tym więcej, że owo przeciwroszczenie okazuje się podobne czy nawet tego samego rodzaju, co sprawa tocząca się już przed sądem, super alia simili vel in equali questione. Tymczasem Statuty rozstrzygają kwestie inaczej: roszczeń wzajemnych łączyć $z$ sobą nie wolno. Pozwany nie może $\mathrm{w}$ toczącym się procesie wystąpić z przeciwroszczeniem, non poterit, lecz musi pozwać powoda w nowym postępowaniu przed sądem dla niego (powoda) właściwym - sed suam litem aut causam coram iudice competenti $[. .$.$] agitabit { }^{33}$. Mimo tego rozstrzygnięcia, jeszcze nie wszystko dla nas jasne.

7.2. Uprzytomnijmy sobie omawianą sytuację ponownie: powód A podlega prawu polskiemu, pozwany B - niemieckiemu. Powód, zgodnie z zasadą actor sequitur..., powołuje swego przeciwnika przed sąd prawa niemieckiego. Nie jest to wszakże sąd dla niego, powoda, właściwy, iudex competens, gdy on (A) znajdzie się w roli dłużnika. Wówczas musi powód-wierzyciel (B) wystąpić przeciw niemu z osobnym powództwem przed polskim sądem; to zrozumiale. Ale jaki sąd kompetentny, gdy ów B, pozwany przed niemieckim sądem, pragnie wystąpić do polskiego powoda $\mathrm{A}$ ze wspomnianym przeciwroszczeniem? Również wówczas stosuje się wskazaną wyżej regułę! Zatem pozwany B, mający przeciwroszczenie do A, nie może wyjść $\mathrm{z}$ nim w toczącym się już przed sądem niemieckim procesie, co wydawałoby się racjonalne ze względu na oszczędność procesową i ewentualną kompensatę roszczeń, lecz musi wytoczyć nowe powództwo przed właściwym

32 Gdyby podlegal również prawu niemieckiemu, nie byłoby problemu.

${ }^{33}$ Hube II, s. 161, trafnie wyjaśnia postanowienie: pozwany wdawszy się w sprawę, może wystąpić przeciw powodowi z rekonwencją w podobnej sprawie, wszakże o tyle, o ile powód obowiązany odpowiadać przed tym samym sędzią. 
dla powoda sądem, sądem polskim! Zatem A jako powód występuje $\mathrm{z}$ procesem przed sądem niemieckim, właściwym dla pozwanego B. Przed tym samym sądem niemieckim tenże A nie odpowiada $\mathrm{w}$ żadnym razie, nawet $\mathrm{w}$ wypadku przeciwroszczenia osoby B. Dla rozstrzygnięcia sporu należy wytoczyć nowy proces przed sądem polskim!

7.3. Jakiż $\mathrm{z}$ tych spostrzeżeń wysnujemy wniosek szerszy? W czasach Kazimierza mamy do czynienia z całkowitym rozdziałem obydwu wymiarów sprawiedliwości: polskiego i niemieckiego. Innymi słowy, przed sądem niemieckim, w procesie wytoczonym przez A, żyjącego według prawa polskiego, nie może pozwany $\mathrm{B}$, rządzący się prawem niemieckim, wystąpić nawet $\mathrm{z}$ przeciwroszczeniem do $\mathrm{A}^{34}$. Zatem reguła kompetencji forum pozwanego przeprowadzona $w$ Statutach ze skrajną konsekwencją, wręcz absurdalną, bo prowadzącą - obawiamy się - do pieniactwa!

\section{Kwestia trzecia, incendiarii, B IV, art. 32.}

8.1. Statuty respektują sankcję stosowaną $w$ prawie cesarskim wobec podpalaczy: podlegają oni karze śmierci i to kwalifikowanej ${ }^{35}$, de lege imperiali clara luce nobis constat, quomodo incendiarii et exustores voluntarii domorum, horreorum aut quorumvis bonorum morte crudeli et impiissima puniantur ${ }^{36}$.

8.2. Przeciwstawiają się natomiast innej praktyce, uznawanej widocznie przez toż cesarskie prawo, a mianowicie przysługującemu według niego podpalaczowi patrocinium $\mathrm{w}$ postaci azylu kościelnego. W prawie polskim z niego on nie korzysta, quibus

${ }^{34}$ Reguła nie obowiązuje w sądzie soltysim: przewodniczący w nim sołtys - stwierdzaja to teksty wielokrotnic - iure Polonico et Theutonico iudicabit.

35 Por. M. H a ndelsm a n, Prawo karne..., s. 101.

36 Zauważmy wszakże, że według art. 10 Statutów za podpalenie grozi kara siedemdziesiąt, idąca na rzecz fiskusa. 
[incendiariis] eciam inventis, si ad ecclesiam fugiant, patrocinium nullum ex hoc debeant obtinere ${ }^{37}$.

8.3. W analizowanym artykule Statuty zajęły się drugim jeszcze, odnoszącym się do podpalaczy, zagadnieniem: przestępcy ci, by uniknąć odpowiedzialności karnej, ut accionem propositam contra eos eludant vel claudant, uciekają do miast i wsi lokowanych na prawie niemieckim, consueverunt tales omnes [...] in civitatibus vel villis Teutunicalibus permanere. Tam - co nas zresztą zdumiewa - ochronę przed odpowiedzialnością zapewnia im prawo niemieckie, bronią się oni per iuris Teutonici defensionemi ${ }^{38}$. W następstwie tego wybiegu zbrodnie pozostają bezkarne - et sic [...] talium malefactorum crimina remanent impunita. Co gorsza, dzieje się to często - sepius, ut plurimum. Czyżby więc obok azylu kościelnego, którego Statuty odmawiają stanowczo podpalaczowi, utrzymywal się dotąd drugi azyl, dość zresztą zaskakujący, przysługujący osadom lokowanym na prawie niemieckim?

8.4. $\mathrm{Z}$ taką ucieczką przed odpowiedzialnością król się nie godzi. Przeto za radą baronów stanowi - unde de nostrorum baronum basso consilio statuimus: oskarżonym o podpalenie (accusati de crimine incendii sive exustionis) nie pomoże ucieczka do miast $\mathrm{i}$ wsi niemieckich - (ut eciam inventi in civitatibus aut villis Theutunicalibus). Zostaną oni pociągnięci poza właściwy dla nich sąd (extra forum eorum trahantur) - jest nim sąd prawa niemieckiego - i stawieni przed właściwego sędziego (coram iudice competenti tenebuntur respondere), gdzie będą osądzeni i właściwie ukarani - sentenciari et puniri pena digna debebunt iuxta exigenciam criminis et eius probacionem. Całe

37 Odrzucając wspomnianą cesarską praktykę, ustawodawca polski uzasadnia swe stanowisko potwornością przestępstwa - propter dampnati criminis sevitatem.

${ }^{38}$ Por. M. Handelsm a n, Prawo karne..., s. 102-103, 183. 
postępowanie toczyć się będzie według prawa polskiego, et in iure Polonico tantum ${ }^{39}$; oczywiście przed polskim sądem.

Zaakcentujmy: nawet lokowani na niemieckim prawie osadnicy wiejscy i miejscy, oskarżeni o podpalenie, nie będą odpowiadać przed właściwym dla nich sądem niemieckim, według prawa niemieckiego, lecz przed sądem polskim, gdzie zastosuje się normy polskie ${ }^{40}$. Wobec incendiarii obojętna zatem ich ewentualna podległość osobista prawu niemieckiemu: wyłączają ją i polskie forum, i polskie ius, i sądy, i prawo polskie ${ }^{41}$.

9. Kwestia czwarta: gwalt niewieści - virgines stuprant, mulieres polluunt violenter, B. IV, art. $\mathbf{3 3}^{42}$.

9.1. Przestępcy, dopuszczający się gwałtu na kobietach - opressores virginum aut mulierum, zatrzymani - auretenti vel irretiti, albo przyłapani na gorącym uczynku - vel in recenti ${ }^{43}$, jeśli przy tym gwałcone podniosły krzyk (si proclamaverunt) ${ }^{44}$, zostaja stawieni przed sąd (polski!) i tam obwinieni przez pokrzywdzone - impetuntur ab eis. Przed sądem owi sprawcy usiłują bronić się prawem niemieckim - iure Teutonico volunt se tueri, tzn. nie chcą uznać kompetencji sądu polskiego. I w tym wypadku

39 Bez znaczenia występujący w niektórych rękopisach Statutów wariant tamen.

${ }^{40}$ M. H andelsman, Prawo karne..., s. 102; por. też ibidem, s. 182. Zauważ, że w art. 27 Statuta terrestria in conventionibus Cracoviensi et Wartensi laudata, mówiącym o spowodowaniu pożaru lasu, przeciwstawia się również prawo polskie, według którego jedynie (tantum), ma przestępca odpowiadać, innemu bliżej nie określonemu ius, którym może być tylko prawo niemieckie.

${ }^{41}$ Hube II, s. 178; przekonanego o dokonanie podpalenia - quicumque de incendio fuerit convictus, skazuje się na karę siedemdziesiąt, ibidem, s. 205.

42 Hube II, s. 222.

${ }^{43}$ Czy to nie zwykły dla Statutów pleonazm?

${ }^{44}$ Brak krzyku świadczyłby o tym, że przeciwko czynowi nie bardzo oponowały. 
czynią to jedynie dlatego, by łatwiej uchylić się od karnej odpowiedzialności - ut facilius eludant commissi criminis accionem. Statuty postanawiają przeto, że tacy przestępcy odpowiadać będą przed kompetentnym sądem - coram iudice competenti teneantur respondere. Oczywiście, skoro proces toczyć się ma według prawa polskiego (iure Polonico), właściwym dla nich będzie sędzia polski. Przezeń zostaną oni ukarani w zależności od kwalifikacji zbrodni - puniri iuxta commissi criminis qualitatem; naturalnie zgodnie $\mathrm{z}$ tym polskim prawem! ${ }^{45}$

9.2. Że faktycznie stosowano powyższe postanowienie wobec siedzących na prawie niemieckim poddanych, poświadcza niedwuznacznie - gratka dla historyka nieczęsta - akt praktyki z 1348 r.: concedimus eciam sculteto, quod si unquam suus kmeto pro suo excessu secundum statutum terre a suo iure [Teutonico] ad ius Polonicum tractus fuerit... ${ }^{46}$.

10. Kwestia piąta: recesja (zbiegostwo) kmiecia ${ }^{47}$ : cum a nobis [rege] sive a quocunque alio domino nobis subiecto kmetho fugerit; recesserit fugitive ${ }^{48}$; zbieg zwie się fugiens, fugitivus ${ }^{49}$, profugus (Os. II, art. 158) ${ }^{50}$.

${ }_{45}$ M. Handelsma n, Prawo karne..., s. 169. O dalszym postępowaniu z gwałcicielami kobiet Hube II, s. 177, 216; por. też Hube I, s. 149.

${ }^{46} \mathrm{KDW} 2$, nr 1279; por. Hube II, s. 76, przyp. 2, s. 167. Powolany tekst nie ogranicza się najprawdopodobniej do jednego tylko przestępstwa, zniewolenia, lecz dotyczy jakiegokolwiek excessus.

${ }^{47}$ Brak w Statutach rozróżnienia kategorii ludności, rozróżnienia spotykanego w akcie Kazimierza Wielkiego z 1358 r.

${ }^{48} \mathrm{~W}$ terminologii Statutów fugere i recedere są niemal synonimami. W art. 63 Constitutiones et iura terrae Lanciciensis dojdzie jeszcze trzeci termin: (a dominis ipsorum) surgere, co odda się polskim wstać.

${ }^{49} \mathrm{~W}$ art. 22. wyd. Hubego synonimem do fugitivi jest też wyraz divagantes; wszakże tu nie chodzi o zbiegostwo.

${ }^{50}$ Hube II, s. 222-223. 
10.1. Przestępstwo zbiegostwa ${ }^{51}$ ma za przesłankę trwałe związanie chłopa $\mathrm{z}$ gruntem. Co do tego faktu normy statutowe okazują się stanowcze: chłopu nie wolno odejść, zarówno gdy siedział:

(1) na prawie polskim: nequaquam kmeto recedat a suo domino, czy też

(2) na prawie niemieckim: cum vero in iure Theutunico kmeto est locatus, idem fugere sive recedere nequeat nullo modo.

Pod tym względem - widzimy - nie ma żadnej różnicy między pozycją chłopa siedzącego na prawie polskim czy niemieckim; przypisanie go do gruntu w obydwu wypadkach równie kategoryczne! To istota poddaństwa.

10.2. Okazuje się wszakże, że $w$ praktyce tego stanowczego zakazu nie przestrzegano. Co więcej, nawet same Statuty go nie respektowały w pełni, skoro w pewnych sytuacjach dopuszczały do zbiegostwa i chłopa ,polskiego", i poddanego „niemieckiego". Była to zatem lex imperfecta. Przy zbiegostwie bowiem rysowały się dwie ewentualności: dochodzi do niego bądź $\mathrm{z}$ winy pana, bądź bez niej - absque culpa sui domini, nulla culpa domini precedente, premissis vero culpis non exstantibus.

10.3. Niekonsekwencji w omawianej kwestii mamy w Statutach więcej: niektóre artykuły są tak zredagowane, jakby recesja była dopuszczalna jedynie wówczas, gdy poddany siedział na prawie polskim - et hoc, quando in iure Polonico sedet, [...] hoc tamen in iure terrestri intelligi volumus. Wbrew temu, i chłop „niemiecki” mógł w pewnych wypadkach legalnie odejść.

10.4. Jest rzeczą oczywistą, że każdy chłop, „polski” i „niemiecki”, odchodząc (zbiegając), rezygnował z własności (podrzędnej) gruntu na rzecz pana. Statuty taką normę wprowadzily tylko przy chłopie niemieckim - domino resignando.

${ }^{51}$ Nie pomieścil go na liście przewinień Hube II, s. 134-145. 
10.5. Odchodzący kmieć na prawie polskim spełnić winien trzy wymogi, utrwalone zwyczajem - iuxta consuetudinem hactenus observatam:

(1) co do terminu: tylko na Boże Narodzenie - solum in Nativitate Domini $^{52}$, a więc po zamknięciu okresu gospodarczego;

(2) zostawiając dom dobrze i należycie ogrodzony - nisi domo relicta bene et decenter septa;

(3) jeśli cieszył się wolnizną przez pewną liczbę lat - si autem libertatem habebat aliquot annis, po odpracowaniu tylu lat, ile $\mathrm{z}$ tej wolnizny korzystal - tot serviat suo domino, $a b$ eodem minime recedendo, quot annorum libertate gaudebat. Do tych postanowień dołączały się dalsze:

(4) zbieg (nawet legalny!) musiał zapłacić dawnemu panu tytułem kary (!) trzy grzywny - idem fugitivus domino suo tres marcas pro pena [...] solvere tenebitur;

(5) ponadto uiścić miał pełną kwotę pieniężną w wysokości płaconego dotąd jednorocznego czynszu - et censum anni ex integro, quem solvebat. Oczywiście pan nie chciał tracić dochodu w okresie przejściowym, zanim innego chłopa osadzi.

10.6. Natomiast chłop siedzący na prawie niemieckim, spełnić musiał następujące warunki:

(1) opłacić czynsz za wszystkie lata wolnizny - nisi tot annis censum exsolvat, quot annis habebat libertatem;

(2) ale nawet wtedy nie wolno mu odejść - nec tunc hoc sibi liceat, jeśli

a) nie sprzeda swego gospodarstwa panu - nisi hereditate sibi [domino] vendita, albo

b) nie pozostawi na swoim gospodarstwie równie zamożnego kmiecia - nisi eque divitem loco sui kmetonem constituat et dimittat ${ }^{53}$;

${ }^{52}$ Hube II, s. 224.

${ }_{53}$ Jak stara to praktyka, dowodzi wczesny akt śląski z 1206 r.: ...ut preter alias pensiones, quas de pacto debent, nullus eorum inde recedat, nisi posito loco suo alio, qui tantundem solvat, SUb 1, nr 101. Wątpliwości co do 
(3) ponadto winien opuszczane pola całkowicie wykarczować i je uprawić - aut agris suis in totum excultis, extirpatis oraz dokonać zasiewów zimowych i letnich - et conseminatis hiemalibus et estivalibus in eisdem. Wtedy dopiero może odejść - et tunc demum recedere permittatur ${ }^{54}$.

10.7. Jakie między tymi postanowieniami podobieństwa i różnice? W ujęciu warunków recesji występują w dużym stopniu podobieństwa, a jedynie Statuty używają odmiennych w obydwu wypadkach sformułowań. W rzeczywistości bowiem:

10.7.1. Drugi wymóg prawa polskiego (dom dobrze ogrodzony) pokrywa się - wolno mniemać - z punktem 3. prawa niemieckiego (pola obsiane itd., a więc całe gospodarstwo postawione na należytym poziomie).

10.7.2. Punkt 3. dotyczący chłopa polskiego, pokrywa się z punktem 1. odnoszącym się do chłopa niemieckiego: w obydwu wypadkach zagwarantowana panu rekompensata za lata wolnizny.

10.7.3. Sądzimy też, że termin recesji, Boże Narodzenie, obowiązywał w obydwu prawach ${ }^{55}$.

autentyczności tego aktu, podniesione dawniej przez historyków niemieckich, a podzielone przez T. T y ca, Poczqtki kolonizacji wiejskiej na prawie niemieckim $w$ Wielkopolsce (1200-1333), Poznań 1924, s. 79, nie wydaja się uzasadnione R. Grodeckiemu, Wole i Lgoty. Przyczynek do dziejów osadnictwa w średniowiecznej Polsce, [w:] Studia z historii spolecznej i gospodarczej poświęcone prof. Franciszkowi Bujakowi, Lwów 1931, s. 55 przyp. 67. Za autentyk poczytuje go również wydawca nowego Schlesisches Urkundenbuch.

${ }^{54}$ Dodajmy jeszcze, że przy opuszczaniu siedzib byli chłopi obowiązani połowę szczepów wszczepionych i już zakorzenionych (plantationes incertae et radicatae), choćby były ich wlasne (etiamsi fuerint propriae), pozostawić na ziemi lub siedlisku, które dotąd trzymali.

s5 Potwierdzenie tego zwyczaju w przywileju rozjemczym Kazimierza Wielkiego z 1358 r., (KDW 3, nr 1369): in festo quolibet Nativitatis domini nostri; stąd przysłowie: na św. Szczepan każdy sobiepan. 
10.8. Przyjrzyjmy się $\mathrm{z}$ kolei różnicom. Zasadniczą widzimy w obowiązku polskiego kmiecia do opłat gotówką (3 grzywny oraz suma odpowiadająca rocznemu czynszowi).

10.9. W wypadku prawa niemieckiego przewiduje się sprzedaż gruntu, $i$ to albo innemu kmieciowi równie zamożnemu - kmethonem eque divitem, albo panu - hereditate sibi [domino] vendita.

11.1. Wspomniane ograniczenia wychodu kmieci były korygowane przez obowiązujące zwyczaje. Albowiem w Polsce równocześnie obowiązywała inna reguła, sprzeczna ze stwierdzoną wyżej, reguła ujęta w znanej frazie niemieckiej: Stadtluft macht frei. Chłop, który uszedł do miasta czy gdziekolwiek indziej, choćby bezprawnie ${ }^{56}$, stawał się po pewnym czasie wolny od roszczeń swego pana - a domino suo libertabitur fugitivus antedictus. Zatem poddany miał możność zdobycia wolności niejako przez zasiedzenie! Bezwzględna, zdawałoby się, wspomniana wyżej więź nie pozbawiała poddanego wszelkiej swobody: nawet on, uciekając (fugiens), w pewnych wypadkach nabywa prawo, i us acquirit. Chodzi tu oczywiście o akceptacje jego odejścia; staje się ono niezaczepialne. Wieśniak będąc jakoś wolny, mógł więc pójść, gdzie chciał - recedere poterit, quo placebit, a więc - co domyślne - albo osiedlić się w mieście, albo też zawrzeć nową umowę osadniczą, $\mathrm{z}$ dowolnym panem; przy czym - co istotne - dotychczasowy pan nie mógł go więcej ścigać.

Chłop zatem zarówno według prawa ziemskiego, jak i niemieckiego zachował i zdolność prawną, i (w ograniczonym stopniu) zdolność do działania: móg1 prawnie odejść (uciec).

Statutom, które raz traktują go jako przypisanego do gruntu, raz jako korzystającego ze swobody odejścia, zarzucić zatem musimy brak konsekwencji.

56 O prawnej ucieczce, zob. niżej, ust. 11.3. 
11.2. Przepisy, obowiązujące $w$ Polsce, otwierały dalszą legalną furtkę, dającą ludności wiejskiej swobodę odejścia. Mianowicie znają one pojęcie winy pańskiej: do zbiegostwa dojść zatem może $\mathrm{z}$ winy seniora.

11.3. Statuty wymieniają taksatywnie, co się poczytuje za owe winy pańskie - culpe vero, propter quas licitum sit a domino suo fugere cmetoni, sunt hec:

(1) ekskomunika pana ${ }^{57}$ - cum dominus propter suum excommunicatur delictum, i z tego powodu kmiecie zostają przez rok pozbawieni kościelnego pochówku - et ob hoc kmetones privantur ecclesiastica sepultura;

(2) gdy pan wsi gdziekolwiek zniewolił swoją poddankę - quando dominus ville in quocumque loco suam villanam oppresserit violenter;

(3) jeśli $\mathrm{z}$ powodu winy pana chłopi są ciążeni - cum ob culpam domini pignora fuerint recepta eisdem [kmetonibus].

11.4. O którymkolwiek $\mathrm{z}$ tych faktów będzie wiadomo - postquam de hoc constabit, nie tylko krewni zniewolonej - nedum parentes oppresse - domyślamy się, że sprawa ma się identycznie przy innych winach - lecz także wszyscy wieśniacy, zamieszkujący wieś, w której się wspomniane zło wydarzyło - verum eciam omnes villani, ubi hoc factum exstiterit, mogą o jakiejkolwiek porze - hora quacunque (a wiẹc - sądzimy - także nocą), swobodnie i bezkarnie odejść - recedendi liberam habeant potestatem, [...] possint fugere ab eodem, [...] idem liceat eis facere; absque impedimento.

${ }^{57}$ Stanowisko władców świeckich wobec ekskomunikowanych charakteryzuje doskonale przywilej księcia Henryka z 1298 r., KDW $3 \mathrm{nr}$ 787; fiskus nie wahał się kościelnej sankcji wykorzystać dla siebie; w skrajnym wypadku posuwal się do konfiskaty majątku - promittimus eciam, quod excommunicatos volumus in omnibus actibus legittimis evitare; et si ultra annum in excommunicatione iacuerint, bona excommunicatorum nostro fisco applicabimus, satisfaciendo ecclesiis de eisdem, prout vel in quanto ipsi excommunicati fuerant ecclesiis obligati. 
11.5. Osobny artykuł dorzuca jeszcze postanowienie uzupełniające, skierowane przeciwko panu, który się gwałtu dopuścil: ciemiężyciel tego rodzaju - oppressor huius modi, czy pan wsi - seu ville dominus, nie może zbiegających chłopów zatrzymywać (siłą) - ipsos detinere audeat, ani ich gnębić - seu in aliquo molestare. Innymi słowy: poddani mogą odejść bez przeszkód - absque impedimento quolibet. Tyle o zbiegach legalnych.

12.1. Statuty zawierają również postanowienia o tym, w jaki sposób może pan odzyskać zbiega przy ucieczce bezprawnej. Musi on wystąpić na drogę sądową $z$ powództwem ${ }^{58}$. Przeciwko komu je skieruje? Nasuwały się tu dwie ewentualności, zależnie od tego, dokąd zbiegły się udał: albo do innej wsi pod innego pana, albo też do miasta. Jeśli osiadł w innej wsi, pozwanym będzie nie sam zbieg, lecz nowy pan, u którego kmieć osiadł; oczywiście sprawę rozpatrzy sąd ziemski, właściwy dla pozwanego pana.

12.2. Co więcej, w omówionym wypadku sankcja spotka nie tylko samego zbiega (powrót pod starego pana), ale także nowego pana, który zbiega przyjął. Ten bowiem, poza obowiązkiem zwrotu owego zbiega, ponosił karę piętnadziesta - penam, que dicitur piętnadzieścia, solvere teneatur. Statuty nie podają poborcy tej kary; chyba był nim dawny pan ${ }^{59}$.

12.3. A gdy zbieg zamieszkał w mieście? Kompetentnym będzie wówczas mimo to nie sąd miejski, lecz sąd ziemski, właściwy dla powoda-pana. Zdajemy sobie dobrze sprawę ze słabej pozycji pozwanego $\mathrm{w}$ tym procesie chłopa. Na jedno tylko mógł liczyć: na zasiedzenie wolności.

${ }^{58} \mathrm{Z}$ równą racją można by pisać o skardze: średniowiecze - stwierdziliśmy

- traktowało zbiegostwo jako przestępstwo.

59 Dla fiskusa - nostre camere applicando, zastrzegały Statuty karę „siedemdziesiąt", por. art. 7, 9-10. 
12.4. Albowiem Statuty przewidują taką możliwość. Mianowicie pan, od którego chłop zbiegł, jest wiązany terminem. Dochodzić mógł swego poddanego tylko w ciągu jednego roku - infra annum. Jeżeli $\mathrm{w}$ tym czasie tego kroku nie poczyni, traci do zbiega prawo. Tym samym staje się on wolny - libertabitur. Bierne, utrzymujące się przez rok zachowanie pana świadczy po prostu o rezygnacji z kmiecia. Oczywiście ta wolność zbiegłego jest dość względna: wolny będzie od nagabywań dawnego pana; tekst mówi wyraźnie: a suo domino libertabitur, i nic więcej. Ów zbieg faktycznie stał się już poddanym nowego pana, a tym samym żyje nadal w poddańczej zależności. Praktycznie zatem swobodny byl tylko w wyborze seniora.

12.5. A gdy zbiegł do miasta, a pan nie wystąpił z powództwem? Chyba wtedy jako wolny zasilał kadry miejskiego proletariatu, podlegając jedynie władzom miejskim.

12.6. W Statutach spotykamy się już, w oczywistym interesie dawnego pana, $z$ wyraźną tendencją do ograniczenia nawet tej względnej swobody kmiecej. Mianowicie postanawia się w nich, że początek biegu przedawnienia liczy się nie od chwili ucieczki, lecz dopiero od momentu, gdy pan dowiedział się o miejscu jego pobytu - idem fugiens nullum ius acquirit tamdiu, quamdiu domino suo de mansione sua non constabit. I powtórnie, tym razem pozytywnie: si domino suo de mansione constiterit.

12.7. Zresztą Statuty nie są i w omawianej kwestii konsekwentne. Inny bowiem artykuł przekreśla w całości przytoczoną wyżej regułę wychodu. Rozpatrując bowiem to samo zagadnienie ponownie, ustawodawca zastanawia się w nim, czy pan może dochodzić zbiega po wskazanym wyżej terminie jednorocznym - (si) post annum repetere voluerit. $\mathrm{Na}$ to pytanie daja tym razem odpowiedź pozytywną: iure suo sibi licebit hec facere ${ }^{60}$.

${ }^{60}$ Redakcja artykulu pozostaje niejasna, a wydawca dla ratowania jego sensu uzupełnił go spójnikiem si; por. też kwestię poruszoną w ustępie następnym. 
Rozwiązanie to jest zatem świadectwem rysującej się nowej tendencji, zmierzającej do dalszego skrępowania kmiecia ${ }^{61}$.

12.8. Ale to jeszcze nie jej kres. Oto dla zapobieżenia spustoszeniu majątków ziemskich wskutek opuszczania ich przez poddanych, kmieci i innych mieszkańców wsi - cmetones seu incolae, na wniosek baronów, a w ich wyraźnym interesie, wydano nowe, ograniczające chłopów postanowienie: jednorazowo, bez pozwolenia pana, nie więcej niż jeden lub dwóch poddanych może ustą̧pić $\mathrm{z}$ jednej wsi i przenieść się do drugiej ${ }^{62}$. Reakcja to zapewne na występujące zjawisko: panowie, chcąc zaludnić swoje osady, skłonni byli iść na ustępstwa wobec przybyszów!

\subsection{Sądownictwo.}

13.1.1. Statuty Kazimierzowskie uznają w zasadzie równorzędność sądów prawa polskiego i niemieckiego.

13.1.2. Regułą jest forum pozwanego.

13.1.3. Wszakże od niej w pewnych sytuacjach pojawiają się wyjątki, w których górę bierze forum powoda-Polaka, a więc sprawa idzie tym samym przed sądy polskie. Ich kompetencja jest wylączna w wypadku zbrodni podpalenia, gwałtu niewieściego

61 Zważmy na wadliwe wręcz sformulowanie Os. art. 158: jeśli nie zachodzi wina pana, idem fugiens nullum ius acquirit tamdiu, quamdiu domino suo de mansione sua non constabit. Secus si domino suo de mansione constiterit et infra annum ipsum iure non pecierit, extunc... i tu oczekiwalibyśmy jedynie logicznego następstwa: idem fugiens ius acquirit et a domino suo libertabitur fugitivus antedictus. Tymczasem $w$ to miejsce weszła fraza nieoczekiwana, a więc mamy do czynienia $\mathrm{z}$ anakolutem: repetere voluerit, iure suo sibi licebit hoc facere, niezgodna $\mathrm{z}$ całym tokiem rozumowania autora, który żąda stanowczo czego innego, a mianowicie sformułowania opozycyjnego, wskazanego wyżej. Wydawca z tej niekonsekwencji redaktora Statutów zdawał sobie dobrze sprawę, a chcąc nadać postanowieniu jakiś sens, uzupełnia je spójnikiem si, co i tak nie ratuje sytuacji.

${ }^{62} \mathrm{~W}$ tym przypadku - sądzić wolno - nie biorą Statuty pod uwage winy pana. 
i zbiegostwa. Wówczas to bez względu na prawo osobiste przestępcy, a więc nawet, gdy rządzi się on prawem niemieckim, wlaściwy dla rozstrzygnięcia sporu jest sąd polski, a więc sąd właściwy dla powoda.

13.1.4. Sądy polskie stosują normy polskie. Statuty są świadectwem zdecydowanego zwycięstwa consuetudines Polonorum nad ius Teutonicum. Kazimierz Wielki śmiało uprzywilejowuje prawo polskie.

\subsection{Sytuacja chłopów.}

13.2.1. Z postanowień statutowych przebija wyraźnie zmierzch doby kolonizacyjnej. Wówczas to chodziło o skłonienie rolnika, Polaka czy Niemca, do osiedlenia się na gruncie pańskim. Chłopa-kolonistę ceniono zatem wysoko, co znalazło wyraz. w nadaniu mu jednego łanu na własność, acz podrzędną. Kmieć stawał się dziedzicznym wlaścicielem (heres), a posiadany przezeń łan - jego dziedziczną wlasnością (hereditas). To była dlań oferta wyjątkowo korzystna.

13.2.2. W następstwie prowadzonej od dłuższego czasu intensywnej kolonizacji oraz - jak można sądzić - podniesienia standardu życiowego wsi doszło do rozrodzenia się ludności; zwiększyła się przeto liczba mieszkańców ${ }^{63}$. W związku z tą zwiększoną „podażą" doszło do odwrócenia pozycji, co umożliwi daleko idącą eksploatację ludności wiejskiej.

13.2.3. Wbrew zatem utrzymującej się po dziś dzień opinii Hubego, jakoby Statuty rozciągnęły swą opiekę nad (biednym rycerstwem i) włościanami ${ }^{64}$, stwierdzić musimy, że wzięły $\mathrm{w}$ nich górę interesy pańskie, interesy właściciela ziemskiego. Im podporządkowano obecnie wszystko. W konsekwencji wszędzie tam, gdzie wydawały się one zagrożone, doszło do wyparcia przepisów plebejskiego prawa niemieckiego - ius Teutonicum,

${ }^{63} \mathrm{O}$ zwiększeniu się liczby ludności w następstwie kolonizacji pisze J. J. M e n ze l, Die schlesischen..., s. 288.

${ }^{64}$ Hube II, s. 179-180; por. przyp. następny. 
przez polskie normy zwyczajowe czy przez stanowione w interesie stanu rycerskiego, prawo rycerskie - ius militare. W rezultacie Statuty Kazimierzowskie dają świadectwo zwycięstwu prawa polskiego nad prawem niemieckim, prawa rycerskiego nad prawem chłopskim. To one, wypierając obce prawo, ius Teutonicum, stanowią milowy krok do wytworzenia się wtórnego, zaostrzonego poddaństwa.

13.2.4. Król Kazimierz rysuje się nam zatem jako zdecydowany przeciwnik plebejskiego $\mathrm{w}$ gruncie rzeczy prawa niemieckiego i jako obrońca rycerskich norm polskich. Tym samym na miano króla chłopów ${ }^{65}$ stanowczo nie zasłużył ${ }^{66}$. To historyczne nieporozumienie!

\section{4.}

De foro competenti, B IV, art. 31

Cum actor forum undique sequi debeat, volumus, ut si quis in iudicio iuris Tewthunici contra reum suam accionem dirigit aut proponit, reus accionem vel actorem ibidem super alia questione simili vel in equali reconvenire non poterit, sed suam litem aut causam coram iudice competenti, cum voluerit, agitabit.

\section{De foro competenti, B IV, art. 32}

Ex lege imperiali clara luce nobis constat, quomodo incendiarii et exustores voluntarii domorum, horreorum aut quorumvis bo-

${ }^{65}$ Trudno zgodzić się z tezą głoszoną przez Hubego, jakoby statut wiślicki zajmował się „rozciągnieniem prawnej opieki nad stanem włościańskim i - gdzie można było - wyrównaniem pozycji jego społecznej ze stanowiskiem klas wyższych". O takim wyrównaniu nie myślal wówczas nikt! Znakomity autor widział w Kazimierzu obrońcę klas słabych i uciśnionych, króla chłopów. (Hube II, s. 180), którym naprawdę nigdy nie byl. Tak go widzial Hube, skoro pisal: ,czyż więc niesłusznie nazywano Kazimierza królem chłopów".

${ }^{66}$ Jego chęć zniesienia obowiązku zwózki dziesięcinnych produktów przez chłopów - to w rzeczywistości udana próba szantażu na duchowieństwie. 
norum, morte crudeli et impiissima puniantur. Quibus eciam inventis, si ad ecclesiam fugiant, patrocinium nullum ex hoc debeant obtinere propter dampnati criminis sevitatem. Consueverunt tales omnes, ut manus effugiant iusticie, ipsos punire volencium (!), ut plurimum in civitatibus vel villis Teutunicalibus permanere, ut accionem propositam contra eos eludant vel claudant per iuris Teutunici defensionem. Et sic sepius talium malefactorum crimina emaneant impunita. Unde de nostrorum baronum basso consilio statuimus, ut accusati de crimine incendii sive exustionis, eciam inventi in civitatibus aut villis Theutunicalibus, extra forum eorum trahantur et in iure Polonico tantum coram iudice competenti tenebuntur respondere, sentenciari et puniri pena digna debebunt iuxta exigenciam criminis et eius probacionem.

\section{De foro competenti, B IV, art. 33}

Re vera non solum a malo, sed ab omni specie mali quemlibet viventem sub lege necessarium est abstinere, per quam refrenatur malorum audacia, ut iustorum innocencia tuta consistat. Sane quidem ad fetiditatem corpus suum, ut plurimum, protrahentes et lascivam vitam gerentes, Deum non timentes, nec temporalem penam formidantes, virgines stuprant, mulieres polluunt violenter et quando impetuntur ab eis auretenti vel irretiti, vel in recenti, iure Theutunico volunt se tueri, ut facilius eludant commissi criminis accionem. Visum extitit nostris nobilibus in colloquio generali, quod et nos decernimus perpetuo observandum, ut tales oppressores virginum aut mulierum, si proclamaverunt in recenti, iure Polonico coram iudice competenti teneantur respondere et puniri iuxta commissi criminis qualitatem.

\section{De privilegiis, B IV, art. 35}

Cum secundum patrum sanctorum decreta lex decernat illos amittere privilegii auctoritatem, qui non utuntur in eo concessa sibi potestate, plures sunt nostri milites ius Theutunicum habentes in multis ipsorum villis ex nostra et nostrorum predecessorum gracia eis facta, et tamen iure Theutonico obmisso, tamen secundum ius Polonicum se regunt in quibusdam. Statuimus, 
quod amplius per ius Theutunicum contra agentes non poterint se defensare. Propter quod volumus, quod ubi crimen est commissum, illo iure, quo illa villa tunc usa fuit, debebit iudicari sive terminari.

\section{Capitulum 158, Os. II.}

Preterea statuimus declarando, quod cum a nobis sive a quocumque alio domino nobis subiecto kmetho fugerit absque culpa sui domini, idem fugiens nullum ius acquirit tamdiu quamdiu domino suo de mansione sua non constabit. Secus si domino suo de mansione constiterit et infra annum ipsum iure non pecierit, extunc, (si) post annum repetere voluerit, iure suo sibi licebit hec facere. Qui si profugus austeritatem sive rancorem sui domini reddire timens, eciam iure convictus, noluerit, extunc decrevimus, quod idem fugitivus domino suo tres marcas pro pena et censum anni ex integro, quem solvebat, solvere tenebitur et per hoc a domino suo libertabitur fugitivus antedictus. - Hoc tamen in iure terrestri intelligi volumus.

Quando vero kmetho in iure Theutunico residebat, idem fugere sive recedere nequeat nullomodo, nisi hereditate sibi vendita vel loco sui ad kmethonem eque divitem collocet, aut agris in toto excultis sive extirpatis et seminibus yemalibus et estivalibus seminatis, domino resignando, recedere poterit, quo placebit. 